\title{
Coachende vejledning - en dynamisk vejledningsstil
}

Asbjørn Molly, studieadjunkt/ph.d.-stipendiat, Institut for Læring og Filosofi, Aalborg Universitet.

Sofie Kobayashi, ph.d.-stipendiat, Institut for Naturfagenes Didaktik, Københavns

Universitet.

\section{Reviewet artikel}

Artiklen bidrager med nogle bud på, hvordan ph.d.-vejledere kan gøre brug af coaching for at fremme en mere smidig og laringsfremmende vejledningsstil gennem en skærpet refleksiv forholden sig til de positioneringer, der opstår $i$ samtalen. Litteraturen om ph.d.-vejledning og vejlederudvikling beskriver vejledningsstil som en relativt statisk størrelse, samtidigt med, at 'god' ph.d.-vejledning beskrives som evnen til at tilpasse sin stil efter omstxndighederne. Ved at benytte begreber fra ledelsesbaseret coaching sættes vejledningsstilen i relation til vejledningsfilosofi og vejledningsteknikker. Dernæst præsenteres en positionsmodel fra coaching som et tankeværktøj til, at vejleder kan bevidstgøre sig om de positioner, der indtages i samtalen. Argumentet er, at denne lobende positionering er udslagsgivende for, hoilken vejledningsstil der udfoldes.

\section{Introduktion}

Vi ønsker med denne artikel at komme med et bud på, hvordan coaching som en efterhånden velafprøvet og teoretisk velfunderet samtalepraksis kan bidrage til at styrke kvaliteten af vejledning af ph.d.-studerende. Det fremgår af både universiteternes selvevalueringer (Vestergaard, 2006) og af eksterne evalueringer (Epinion Capacent, 2007) at vejledningen har en central rolle i et ph.d.-forløb, og styrkelse af ph.d.-vejledning er et centralt indsatsområde i lyset af det øgede optag og den større diversitet blandt ph.d.-studerende (Engebretson et al., 2008). Men som WichmannHansen, Eika og Mørcke (2007, s. 17) pointerer, så mangler der forskning med fokus på samtalen: "...hvilke pædagogiske kompetencer bør vejlederen have?", "Hvad kendetegner en vellykket vejledningssamtale?", "Hvilke dialogiske og spørgetekniske færdigheder skal 'den gode vejleder' mestre?" I forskningslitteraturen indrammes disse spørgsmål ofte af begrebet vejledningsstil, og det fremskrives som ideal, at 'den gode vejleder' skal kunne tilpasse sin stil til den enkelte ph.d.-studerende (Pearson \& Brew, 2002). Med vores baggrund i hhv. forskning og undervisning i vejledning og undervisning i coaching kan vi se klare paralleller mellem coaching og vejledning, som kan berige vejledningen. To forhold gør sig gældende her: Dels relationen mellem vejleder og vejledte, som er præget af en asymmetri ift. magtbeføjel- 
ser; derfor vil vi benytte greb og tankefigurer fra en særlig tilgang til coaching, nemlig ledelsesbaseret coaching. Dels det særlige ved vejledning på ph.d.-niveau, fx længden på forløbet og det, at den ph.d.-studerende er en af flere kollegaer i et fagligt fællesskab. Relationen mellem vejleder og vejledt er ikke så veldefineret på ph.d.niveau som på bachelor og specialeniveau, og vejleder har som regel en større andel og interesse i ph.d.-projektet. Der kan i varierende grad være tale om et forskningsfællesskab mellem en senior- og en juniorforsker med risiko for, at vejleder kommer til at overtage for meget af projektet. Dertil kommer det uforudsigelige i en forskningsproces, som betyder, at vejledningen ikke kan planlægges i samme grad som på bachelor- og specialeniveau.

Vi håber i artiklen at introducere nogle forståelser, der med afsæt i systemisk organisatorisk coaching (Moltke \& Molly, 2009) samt ledelsesbaseret coaching (Søholm et al., 2006) kan bidrage til at kaste lys over de processer i samtaleforløbet inden for hvilke, en vejledningsstil folder sig ud. Vi forholder os primært til ph.d.-vejledning, men mange af pointerne vil også have relevans for vejledning generelt. Artiklen falder i tre dele: Først nogle indledende betragtninger om den måde, coaching behandles på i vejledningslitteraturen generelt; dernæst en indkredsen af begrebet vejledningsstil i krydsfeltet mellem vejledningsfilosofi og vejledningsteknikker; og sidst præsenterer vi en model fra coachingens verden, som kan understøtte vejleders løbende bestræbelse på at tilpasse sin vejledningsstil efter situationen.

\section{Coachings relevans for vejledning}

På baggrund af Tofteskov (1996) har en af de grundlæggende forståelser af vejledning i dansk/nordisk sammenhæng ligget i spændet mellem produktvejledning og procesvejledning. I produktvejledning fokuserer vejlederen på at stille forslag og give feedback, som kan bidrage til at skabe det bedst mulige produkt. I procesvejledning er målet, at den studerende skal lære af processen, mens det er mindre vigtigt, om produktet bliver af topkvalitet. Vejleder stiller spørgsmål, der skal hjælpe den studerende med at tænke, skrive og reflektere og derigennem lære af processen. I dette spænd fremhæves procesvejledning ofte som idealet, der bemyndiger den studerende til at tage ejerskab.

Rienecker, Harboe og Jørgensen (2005) tager diskussionen videre og argumenterer for, at begge former for vejledning har sin berettigelse. Der er brug for at udvikle en vejledningsform, som er en blanding af procesvejledning og kriteriebaseret produktvejledning. Hvis man kun procesvejleder, er der risiko for, at den studerende ikke får fornemmelsen af, hvad der skal til for at leve op til fagets kvalitetskriterier. Men hvis man baserer sin vejledning på produktvejledning risikerer man at overtage projektet fra de studerende. Rienecker og kolleger beskriver en tendens mod en idealisering af procesvejledning, mens den reelle praksis i højere grad udmønter sig i produktvej- 
ledning. Som Grant (2000, s. 34) siger, kan det være svært at skifte position fra "speaking knowers to good listeners and probing questioner". Det føles rart at være eksperten. Dette afføder det interessante spørgsmål: Hvad der skal til for at ruste vejledere til i højere grad at procesvejlede? og til, hvordan vejleder bevidst kan skifte mellem proces- og kriteriebaseret produktvejledning i situationen?

Der er klare paralleller mellem procesvejledning og coaching. Alligevel ser Rienecker og kolleger ikke store perspektiver i vejlederen som coach, hvilket hænger sammen med den traditionelle forståelse af coaching som en tilstræbt magtfri samtaleform med coachen i en ikke-vidende, rent nysgerrig position. Anskuet som sådan giver det naturligvis god mening at være skeptisk over for coachingens anvendelighed i vejledningssituationen, hvor magtforholdet er et vilkår på godt og ondt. I takt med at coaching over de sidste 10-15 år har vundet fodfæste som organisatorisk praksis, har begrebsdannelsen om coaching imidlertid forskudt sig. Der er i denne kontekst bred enighed om det uhensigtsmæssige i at stræbe mod det magtfrie rum eller den herredømmefri samtale som ideal i en relation, der er defineret ved en række forskelle i magtbeføjelser og rettigheder (som fx leder-medarbejder-relationen). Coaching er ikke længere at stille spørgsmål, men at indgå i samtaler. Coaching er samtalekunst snarere end spørgekunst (Hede, 2010). Dette efterlader et mere komplekst rum for coachen at agere i, hvor der på den ene side skal tydeliggøres de vilkår, rammer og krav, der fra organisationens side er til den eller de opgaver, coachingsamtalen knytter an til, og på den anden side at skabe de samtalerum, der er så velegnede til at skabe refleksion og læring hos fokuspersonen (Søholm et al., 2006). Coaching som samtalekunst har mange flere greb at byde på, og et af de væsentlige er det, vi præsenterer her: Positionering. I kommunikationsteorien er position et mere dynamisk begreb for de roller, de forskellige aktører indtager i samtaler; en definition, vi vender tilbage til.

Som nævnt i introduktionen ser vi mange relationelle sammenfald mellem vejledningssituationen og den ledelsesbaserede coachingsamtale. Der er klare rammer for, hvad et projekt eller en afhandling skal leve op til af kvalitetskriterier og formalia, og det er vejleders ansvar at disse tydeliggøres samtidigt med, at den vejledte skal understøttes i sin læring og professionelle udvikling. Vejledning foregår på den måde i et spænd mellem kvalitetskontrol og læringsunderstøttelse, og man kan og skal som vejleder naturligvis ikke suspendere egen position som eksperten, der står på skuldrene af den fagtradition, der vejledes inden for, og som vejledte står over for opgaven at indgå i. Særligt i ph.d.-vejledningssituationen, hvor vejledte forventes at udvikle en større grad af selvstændighed i arbejdet end på bachelor- og kandidatniveau, stiller denne balancegang krav om en avanceret bevidsthed om, hvilke positioner vejleder kan indtage undervejs i vejledningsforløbet, samt om en særlig måde at forvalte disse positioner på. 


\section{Vejledningsstil mellem filosofi og teknik}

I deres bog Udviklingsledelse optegner Lievegoed \& Glasl (1997) tre niveauer for det, de kalder en samlet ledelsesmodel. Niveauerne er ledelsesfilosofi, ledelsesstil og ledelsesteknikker; og grundtanken er den, at skal teknikkerne have de intenderede effekter, må der være kongruens mellem filosofien, stilen og teknikkerne. Det nytter fx ikke at anvende systemisk-anerkendende coachingteknikker i forbindelse med MUS, hvis ledelsesfilosofien i øvrigt er præget af hierarkisk tænkning, løbende kontrol af medarbejderne og benhård benchmarking. Dette vil i bedste fald skabe forvirring hos medarbejderne, i værste fald blive opfattet som forsøg på manipulation (Søholm et al., 2006).

I forskningslitteraturen om vejledning beskrives den gode vejleder som den reflekterende praktiker, der gennem refleksion over egen praksis kan tilpasse sin stil efter den individuelle studerende, projektet, faserne i projektet, og hvad situationen ellers byder på (Pearson \& Brew, 2002). Det er vores indtryk, at der på vejledningskurser arbejdes rigtig meget med vejledningsteknikker, så vejleder får udvidet værktøjskassen og derved har grebene til at tilpasse sin vejledningsstil, men, hvad der egentligt menes med vejledningsstil, er sjældent genstand for samme opmærksomhed. Der arbejdes også i mindre grad med den bagvedliggende filosofi, såsom læringsopfattelse, egne værdier, motivationsteorier mv. Det er vores håb at kunne kaste lidt lys ind i dette komplekse samspil ved i det følgende at overføre begreberne fra den samlede ledelsesmodel til vejledning. Baggrunden er, som nævnt, at vi ser mange sammenfald mellem den ledelsesbaserede coachingsamtale og vejledningssamtalen; dog er der forskelle, fx udspiller ledelse sig på væsentligt flere arenaer end vejledning og har derfor en anden grad af kompleksitet. Derudover har ledere mere formel magt og flere beføjelser end vejledere.

Vejledningsfilosofi er udtryk for den grundliggende læringsopfattelse, vejleder arbejder efter, og det er her den enkelte vejleder definerer sin centrale ambition med vejledningen. Vejledningsfilosofien er dels funderet i de værdier, vejleder har udviklet gennem egne erfaringer, dels påvirket af den institutionelle og kulturelle kontekst, vejledningen foregår i. Der findes forskellige teorier, som kan bringes i spil i forbindelse med en udfoldelse af vejledningsfilosofi. Lystbæk (2012) uddrager fire overordnede idehistoriske rationaler eller læringsforståelser, som ofte spiller ind i vejledningssituationen:

- Mesterlære: Vejleder som formidler af rammer og regler og som forvalter af en fagtradition og et fællesskab, som vejledt skal 'opdrages' ind i. Her har vejleder en formativ funktion (Lave \& Wenger, 1991).

- Skolastisk læring: Vejleder som 'gatekeeper' på en formaliseret viden, fokus på at kontrollere og kvalitetssikre vejledtes arbejde ud fra standarder og ved- 
tagne 'sandheder' inden for faget. Her har vejleder en normativ funktion (Schein, 1973).

- Motiverende læring: Vejleder som understøttende og forstærkende ift. vejledtes motivation og tillid til egne evner ift. projektet/opgaven. Her har vejleder en emotiv funktion (se fx Illeris, 2006).

- Reflekterende læring: Vejleder som udforskende og undersøgende af vejledtes forståelse af eget projekt i mødet med fagtraditionen. Her har vejleder en eksplorativ funktion (Handal \& Lauvås, 2006; Schön, 1987).

De fire rationaler beskriver samtidig i meget grove træk udviklingen i dominerende traditioner inden for vestlige læringsforståelser: Fra mesterlære og skolastisk læring over motiverende og til eksplorativ læring. Et eksempel på den sidste og fremherskende læringsforståelse er den reflekterende vejledning, som beskrevet af Handal og Lauvås (2007), hvor vejlederen er sparringspartner i vejledtes egen refleksion over praksis. Udviklingen er måske mest præcist beskrevet som en bølgebevægelse, hvor der på forskellige tidspunkter er en dominerende forståelse, men hvor de øvrige forståelser flyder med under bølgetoppen. Dermed også sagt at et rationale sjældent vil optræde i sin 'rene form', der vil altid være tale om forskellige grader af sammenblandinger. Pointen er, at de forskellige forståelser stiller forskellige muligheder til rådighed for relationsdannelsen mellem vejleder og vejledt - fra et lærer-studerendeforhold til en mere ligeværdig relation.

Vejledningsteknikker dækker over de konkrete redskaber til at guide, rammesætte, motivere, retvise, understøtte, udforske osv. Teknikkerne er ofte det bærende indholdselement på forskellige vejledningskurser, hvor man finder spørgsmålstyper, feedback, spejling og aktiv lytning, ligesom coaching som samtalepraksis føjer sig ind på dette niveau.

Vejledningsstil er vanskeligere at sætte på begreb. I daglig tale opfattes stil vel primært som noget personligt, man ikke uden videre kan lave om på; noget, der knytter sig til identitet. Ifølge Lievegoed og Glasl (1997) handler stil om måden, hvorpå filosofien udleves igennem anvendelse af teknikkerne. Med afsæt i vejleders grundlæggende filosofi og læringsforståelse og gennem anvendelse af de forskellige spørgeog feedbackteknikker sætter stilen sig som et mønster i måden, man vejleder på. Inden for vejledningslitteraturen beskriver Gatfield (2005) stil som en foretrukken personlig stil, som til en vis grad påvirkes af den ph.d.-studerendes respons. Kam (1997) definerer stil som den måde, en vejleder udfører vejledningsprocessen på, og han tolker stil som en manifestation af vejlederens forståelse af den ph.d.-studerendes vejledningsbehov. Eftersom behov varierer mellem studerende, så findes der ikke nogen opskrift på 'god' vejledningspraksis, men kvalitet udvikles, når vejledningsprocessen tilpasses til at møde den enkelte studerendes behov (Kam, 1997). Gurr (2001) beskriver stil som 'hands-on' vs. 'hands-off', altså groft sagt som instruerende 
eller faciliterende (eller uddelegerende) tilpasset den ph.d.-studerendes behov for vejledning. Gurrs ærinde er at facilitere løbende samtaler mellem vejleder og ph.d.studerende om vejledningen. Gennemgående fremskrives dette at kunne tilpasse sin stil til den aktuelle vejledningssituation ofte som en nøgleegenskab ved 'den gode vejleder'.

\section{Vejledningsstil og positionering}

Vores argument er, som også tidligere nævnt, at vejledningsstil er tæt forbundet med de gensidige positioneringer, der er i spil i vejledningssituationen. Positioneringsbegrebet forbindes især med Davies og Harré (1990), hvor positionering betegner de rettigheder og pligter, vi tildeler os selv og hinanden i vores interaktioner i det sociale rum. I positioneringsteori ses talehandlinger, diskursiv praksis og positionering som indbyrdes afhængige. Tanken er, at vi kun kan forstå, hvorfor sociale episoder (fx vejledningssamtaler) udspiller sig, som de gør, hvis vi kender til den kulturelle kontekst og de positioner, der strukturerer samtalen. Positioneringsteori fremstilles ofte som et mere dynamisk alternativ til rolleteorier, idet positioner i modsætning til roller er noget, der konstant produceres og løbende forhandles i de sociale sammenhænge. Den gensidige positionering mellem vejleder og ph.d.-studerende er dermed ikke noget, der ligger fast forud for vejledningsforløbet; det er noget, der opstår som resultat af de diskursive praksisser, der flyder ind i og udvikler sig i interaktionen.

Vejledningsstil er dermed ikke fuldt ud noget, vejlederen kan beslutte sig til. Man kan som vejleder have bestemte intentioner (ud fra den vejledningsfilosofi, man opererer fra), men hvordan, disse intentioner får liv i vejledningen, opstår i mødet med den studerende. Hvis $\mathrm{fx}$ den ph.d.-studerende positionerer sig som uvidende og usikker og dermed positionerer vejleder som eksperten, kan det ikke undgå at påvirke den vejledningsstil, der udfoldes i situationen. Stilen samskabes i relationen og i den positionelle dans, der udfolder sig om denne. Men da vejledningsrelationen er præget af eksplicit asymmetri (fordi den vejledte er afhængig af vejleder på en lang række områder), er det vejleder, der har størst betydning for, hvilken stil der udleves i praksis. Og dermed størst ansvar for kontinuerligt at arbejde for at finde den mest konstruktive stil i den konkrete vejledningssituation.

Fra organisationspsykolog Vibe Strøier (2011) kan vi hente et begrebssæt, der måske kan inspirere vejleder i arbejdet med sin positionering over for vejledt. Strøier arbejder ud fra en eksistentiel-fænomenologisk tilgang (inspireret af den engelske professor Ernesto Spinelli) med tre positioner, coachen kan indtage over for sin fokusperson, som vi, oversat til vejledningssituationen, kan beskrive på denne måde: I den første position forholder vejleder sig åbent og rent nysgerrigt til den ph.d.-studerende; alle erfaringer fra tidligere projekter sættes til side, og fokus vil være på, hvad der adskiller denne ph.d.-studerendes projekt fra alle de andre. Denne position kal- 
der hun MED-positionen: Man rejser med den anden ind i dennes forståelser og har rent fokus på, hvad den ph.d.-studerende vil med sit projekt. I den anden position lader man sig også invitere ind i den ph.d.-studerendes forståelser, men nu med sin egen rygsæk på, så at sige. Her bringer man sin viden og sine erfaringer i spil i mødet med den ph.d.-studerendes tanker om projektet. Denne position kalder hun FOR-positionen: Man træder frem for den anden. I den tredje position træder man skridtet ud ad den andens forståelser og kigger på dem udefra. Her vil man være optaget af, hvad man med sine særlige forudsætninger og kendskab til de rammer og vilkår, der måtte være gældende, får øje på; og man vil bringe disse iagttagelser i spil som enten spørgsmål eller feedback. Denne position kalder hun UDENFORpositionen: Man træder uden for den andens forståelser. Som Strøier skriver, kan bevidstheden om disse tre positioner være god at have i baghovedet, da de fanger "spektret mellem det at have viden om noget som coach men ikke at vide, hvordan det kommer til udtryk hos den person eller de grupper, man coacher." (Strøier, 2011).

Oversat til vejledningssituationen kan de to første positioner kategoriseres som forskellige niveauer af undersøgende, coachende tilgang, mens den sidste mere har karakter af en myndig, vejvisende tilgang. I den sidste betones på denne måde de mere formelle aspekter af relationen mellem vejleder og ph.d.-studerende, mens der i de to første i højere grad tilstræbes en mere uformel og jævnbyrdig relation. Nu kan man jo aldrig i praksis 'lægge sin rygsæk fra sig'; men man kan suspendere den midlertidigt for at forstå, hvad den ph.d.-studerende forstår. Metaforisk er den ph.d.studerende rejsefører i MED-positionen, i FOR-positionen er vejleder og ph.d.studerende rejsefæller, mens vejleder i UDENFOR-positionen er rejsefører.

I det følgende vil vi komme med et mere udfoldet bud på, hvordan en skærpet refleksiv forholden sig til forskellige positioner og positioneringer i vejledningssituationen kan bidrage til en mere smidig og læringsfremmende vejledningsstil.

\section{En positionsmodel for vejledning}

Karl Tomm er mest kendt for sin model over fire forskellige spørgsmålstyper (Tomm, 1988), som bruges flittigt på vejledningskurser. Han har desuden opstillet en model for positioner i samtaler (Strong et al., 2008). Modellen tager, som Tomms øvrige arbejde, afsæt i terapi, og vi vil i det følgende præsentere den oversat til vejledningssituationen. Vi bruger ikke helt de samme ord som Strong og kolleger i deres præsentation af Karl Tomms model, da vi også læner os op ad et foredrag af Karl Tomm i Rambøll Management Consulting i 2011. De betegnelser, vi har valgt på dansk for de fire positioner, afspejler i højere grad, at alle positioner kan være relevante afhængigt af situationen. Modellen er bygget op om to akser, en vertikal og en horisontal, der lagt oven på hinanden danner fire positioner, som vist i figur 1. 
Den vertikale akse kaldes 'råderumsaksen'. Den betegner i hvilken grad vejleders spørgsmål eller feedback har en begrænsende eller en øgende effekt for vejledtes svarmuligheder. Vi kan også kalde det hhv. at lægge tryk på rammen, som vejledtes svar skal tale ind i, hhv. at lægge tryk på råderummet for vejledtes egen tænkning om mulige svar.

Den horisontale akse kaldes 'hensigtsaksen'. Den betegner i hvilken grad vejleder er tavs og lukket om de hypoteser og hensigter, der ligger bag formuleringen af spørgsmål eller feedback, eller er åben og italesættende om samme. Denne akse siger altså noget om graden af metakommunikation om vejleders tanker og intentioner.

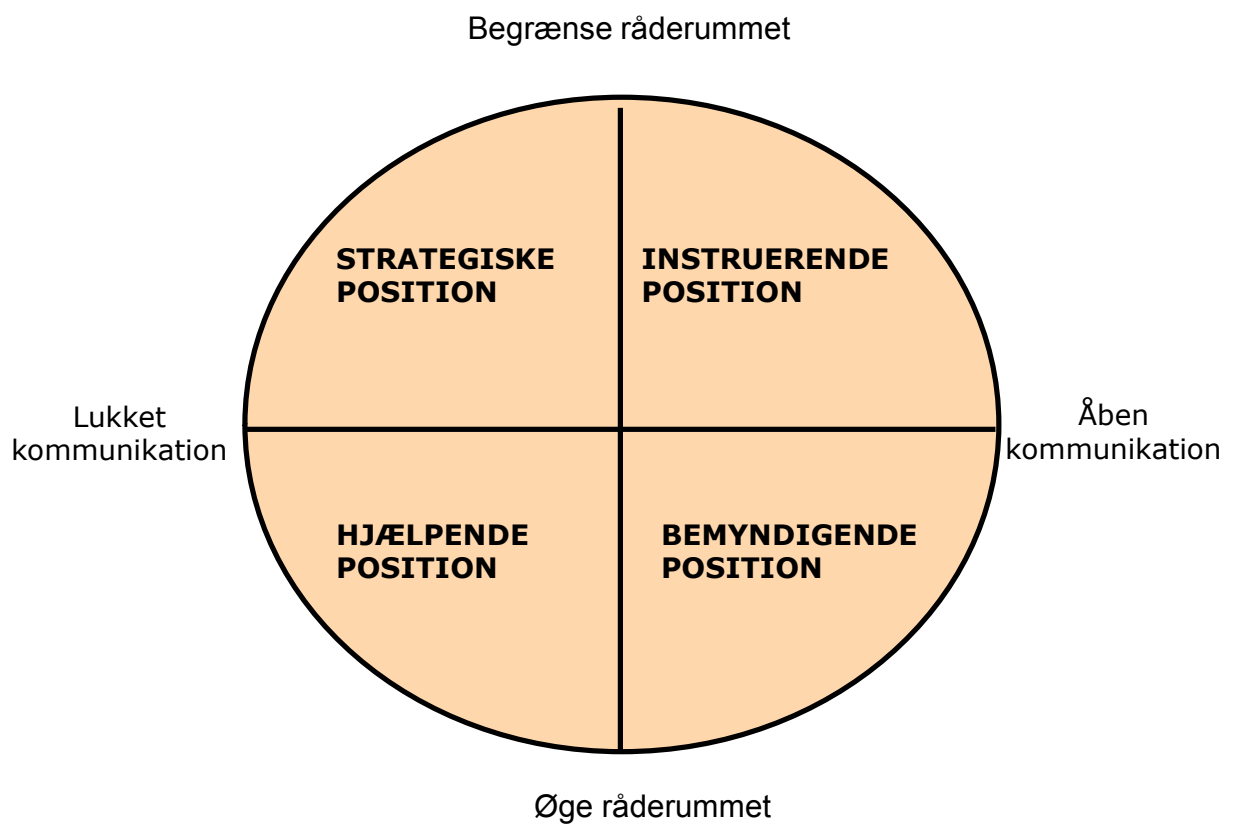

Figur 1: Tomms model for positioner i samtalen (Strong et al., 2008).

De fire positioner giver forskellige muligheder for læring, som vi skal se i det følgende. Fra den 'strategiske position' taler vejleder fra en lukket kommunikation og med henblik på at begrænse vejledtes råderum. Vejleder vil her ofte stille ledende spørgsmål, der har til hensigt at orientere vejledte mod et begrænset antal valgmuligheder; og er ikke tydelig om, hvad der ligger til grund for, at det netop er den eller de muligheder, der peges på, og ikke andre. For eksempel kunne vejleder spørge: Kunne din problemformulering blive mere specifik? Vejledte vil som resultat ofte føle sig styret i bestemte retninger, uden at det er tydeligt for ham, hvorfor disse retninger er bedre end andre. Det kan være rigtig god vejledning at tage styringen og indsnævre råderummet, når der er brug for det, men oftest virker det bedst, når man kommunikerer om hensigten samtidigt. Ellers kan effekten blive, at vejledte bruger sin mentale energi på at forsøge at regne ud, hvad vejleder tænker, er det rigtige svar. Der kan dog være situationer, hvor man med fordel kan være strategisk og netop undlade at være åben om hensigten. Det kunne være, at man giver vejledte en 
overkommelig opgave i laboratoriet for at vedkommende skal få en succesoplevelse og opbygge selvtillid; her ville det ikke fungere at metakommunikere sine intentioner med vejledte.

Fra den 'hjælpende position' taler vejleder ligeledes fra en lukket kommunikation, men med henblik på at øge vejledtes råderum. Et typisk eksempel er, at vejleder foreslår masser af metoder eller litteratur, som den ph.d.-studerende i starten er glad for og forfølger troligt, men så finder ud af er for omfangsrigt, og at det var ment som inspiration. Vejleder har glemt at metakommunikere om hensigten. Det vil fra denne position komme til udtryk i ledende spørgsmål, der peger vejledte i mange konstruktive retninger, men uden at vejledte nødvendigvis bliver klogere på den proces, der førte frem til de nye tanker. Effekten af at kommunikere fra denne position vil ofte være, at vejledt har følt sig hjulpet, men uden at være klar over hvordan.

Fra den 'instruerende position' søger vejleder med spørgsmål og feedback at indsnævre de valgmuligheder, vejledte står over for. Her tager vejleder ekspertkasketten på, men det gøres med en åben kommunikation om, hvilke tanker, hypoteser og intentioner, der ligger bag. Det kan være, at vejleder stiller spørgsmål til en tekst i forhold til fagets kvalitetskriterier eller egne faglige erfaringer, som hun eksplicit deler med den studerende jf. kriteriebaseret produktvejledning (Rienecker et al., 2005). Vejledt vil her opleve sig styret mod et begrænset råderum men på en måde, hvor vejleder er eksplicit om rammerne og åben om sine intentioner med at styre i de bestemte retninger.

Den samme åbenhed er gældende i den 'bemyndigende position', hvor vejleder i tilgift stræber mod maksimalt at åbne det råderum, hun med spørgsmål og feedback orienterer vejledte imod. Her vil vejleder metakommunikerende fortælle, hvad hun vil med sine udsagn, og hun vil dele sine overvejelser om samtalens udvikling og mulige forgreninger. Denne position fremhæves ofte som den ideelle inden for coaching, fordi samtalens indholdsniveau spilles rent over på fokuspersonens banehalvdel, mens coachen varetager procesniveauet.

Både den instruerende og den bemyndigende position er kendetegnet ved, at vejleder lægger sine overvejelser frem og gør dem til en del af vejledningssamtalen, mens hun fra den strategiske og den hjælpende position ikke indvier vejledte i sine overvejelser over læreprocessen omkring vejledningssituationen. Den grundlæggende forskel på de to positionstyper kan i et læringsperspektiv måske indfanges af bibelhistorien om forskellen mellem at give en sulten mand en fisk og at lære ham at fiske; dvs. læring af hhv. første og anden orden (Qvortrup, 2001). Relationen mellem vejleder og vejledt vil tage form efter hvilke positioner, der kommer i spil i samtalen. Overordnet set vil relationen, når der kommunikeres fra den strategiske og den hjælpende position, tendere mod asymmetri med vejledte som den underordnede, der skal lære af 
vejleder. Modsat vil relationen, når der kommunikeres fra den instruerende og den bemyndigende position, tendere mod større ligeværdighed pga. den gennemsigtighed, vejleder udviser om sine overvejelser. Dette ligger i tråd med Dysthes (2002) to vejledningsmodeller - Lærermodellen og Partnerskabsmodellen - hvor lærermodellen bygger på en forståelse af læring som overførsel af viden, mens partnerskabsmodellen bygger på dialog og interaktion som grundlag for (sam-)skabelse af viden. Dysthes argument er, at skal vejledte uddannes til såvel medlem af forskningskulturen som til uafhængig forsker, så kræver det, at vejleder indtager positionen som dialogpartner. Som vi har været inde på, vil vi dog argumentere for, at samtlige fire positioner, afhængig af kontekst, kan være læringsfremmende, og at de således alle bør indgå som del af repertoiret i udviklingen af en dynamisk vejledningsstil.

\section{Sammenfatning}

Positionsmodellen giver for os at se en god ramme inden for hvilken, man som ph.d.vejleder kan tænke sin vejledningsstil sammen med sin vejledningsfilosofi og de vejledningsteknikker, man benytter sig af. Skal man som vejleder udvikle flere muligheder for at tilpasse sin stil til situationen, kræver det i første omgang en bevidstgørelse af de forskellige læringsforståelser, der er med til at forme vejledningsfilosofien. Dernæst kræver det en vis grad af mestring af de coachende spørge- og feedbackteknikker, der kan spille bolden over på vejledtes banehalvdel og understøtte koblingerne mellem faget og den ph.d.-studerendes forståelses- og erfaringshorisont. Men skal disse teknikker hjælpe vejledte til at lære i anden orden, må de ledsages af en åben kommunikation om de tanker, hypoteser og intentioner, som spørgsmålene udspringer af. Der kan naturligvis være situationer, hvor det er hensigtsmæssigt ikke at være åben om sine hensigter og indtage den strategiske eller den hjælpende position, fx over for usikre ph.d.-studerende, der har brug for umiddelbare succesoplevelser for at opbygge større mestringsfølelse. Men med det her introducerede blik for at vejledningsstil i høj grad handler om positionering - hvordan man positionerer sig som vejleder, og hvilke positioneringsmuligheder man giver den ph.d.-studerende i den enkelte samtale og i løbet af vejledningsprocessen - bør man bestræbe sig på at bevæge kommunikationen over i de åbne positioner. Holdes kommunikationen for længe i de lukkede positioner, vil den udmøntede læring med stor sandsynlighed være af første orden, og den ph.d.-studerende vil blive fastholdt $i$ en position som en, der har brug for hjælp.

Coachende vejledning handler på denne måde i mindre grad om at tillære sig spørgsmåls- og feedbackteknikker fra coachingværktøjskassen; det skal man naturligvis også, men skal det have den ønskede effekt, må vejleder have modet til at invitere den vejledte ind i maskinrummet, hvor hypoteser, tanker og læringsforståelser rumsterer og giver fødsel til specifikke spørgsmålstyper og særlige former for afgrænsende eller udforskende feedback. Derved gives grobund for samskabt læring i 
vejledningssituationen. Samtidig vil en vejledning, der bevæger sig mellem den instruerende og den bemyndigende position, kunne være en måde at kombinere procesvejledning og kriteriebaseret produktvejledning. Vi håber, med introduktionen af Karl Tomms positionsmodel som supplement til den mere udbredte spørgsmålsmodel, at have leveret et bud på, hvordan coaching kan bidrage til en mere smidig og læringsfremmende vejledningsstil gennem en skærpet refleksiv forholden sig til de positioneringer, der opstår i samtalen.

Asbjørn Molly, cand.mag. i Litteraturvidenskab og Moderne Kultur, er studieadjunkt/ph.d.-stipendiat ved Aalborg Universitet/København i Proceskonsultation, Forandringsforståelser og Lærende Samtaler. Asbjørn kommer fra en stilling som chefkonsulent i Rambøll Management.

Sofie Kobayashi er agronom og ph.d.-stipendiat ved Institut for Naturfagenes Didaktik ved Københavns Universitet. Sofie underviser i vejledning for ph.d.-studerende og ph.d.-vejledere og forsker $i$ ph.d.-vejledning inden for naturvidenskab.

\section{Litteratur}

Davies, B., \& Harré, R. (1990). Positioning: The discursive production of selves. Journal for the Theory of Social Behaviour, 20(1), 43-63.

Dysthe, O. (2002). Professors as mediators of academic text cultures: An interview study with advisors and master's degree students in three disciplines in a Norwegian university. Written Communication, 19(4), 493-544.

Engebretson, K., Smith, K., McLaughlin, D., Seibold, C., Terrett, G. \& Ryan, E. (2008). The changing reality of research education in Australia and implications for supervision: A review of the literature. Teaching in Higher Education, 13(1), 1-15.

Epinion Capacent. (2007). Undersøgelse af årsager til frafald blandt ph.d.-studerende: Universitets- og Bygningsstyrelsen. Retrieved from http://www.ubst.dk/ publikationer/undersogelse-af-arsager-til-frafald-blandt-ph-d-studerende/ undersogelse-af-arsager-til-frafald-blandt-ph-d-studerende/?searchterm=None

Gatfield, T. (2005). An investigation into PhD supervisory management styles: Development of a dynamic conceptual model and its managerial implications. Journal of Higher Education Policy and Management, 27(3), 311-325.

Grant, B. (2000). Pedagogical issues in research education. Paper presented at the Quality in Postgraduate Research conference, Adelaide.

Gurr, G. M. (2001). Negotiating the 'rackety bridge' - a dynamic model for aligning supervisory style with research student development. Higher Education Research and Development, 20(1).

Handal, G. \& Lauvås, P. (2006). Vejledning og praksisteori: Århus: Klim.

Handal, G. \& Lauvås, P. (2007). Veiledning i de videregående utdannelser. Dansk Universitetspædagogisk Tidsskrift, 2007(3), 4-10.

Hede, T. D. (2010). Coaching. Samtalekunst og ledelsesdisciplin. Frederiksberg: Samfundslitteratur. 
Illeris, K. (2006). Læring (2. reviderede udgave, red.). Frederiksberg: Roskilde Universitetsforlag.

Kam, H. B. (1997). Style and quality in research supervision: the supervisor dependency factor. Higher Education, 34(1), 81-103.

Lave, J. \& Wenger, E. (1991). Situated learning: Legitimate peripheral participation. Cambridge: Cambridge University Press.

Lievegoed, B. \& Glasl, F. (1997). Udviklingsledelse: Fra pionervirksomhed til netværksorganisation. Randers: Ankerhus.

Lystbæk, C. (2012). Refleksion og dilemmaer i vejledning. Paper presented at the CUPP konference, Vordingborg, Denmark. http://ucsj.dk/udvikling/videncentre/ cupp-praktik-og-professioner/konferencer-og-temadage/

Moltke, H. \& Molly, A. (red..). (2009). Systemisk coaching. En grundbog. København: Dansk psykologisk Forlag.

Pearson, M. \& Brew, A. (2002). Research training and supervision development. Studies in Higher Education, 27(2), 135-150.

Qvortrup, L. (2001). Det lærende samfund. Hyperkompleksitet og viden. København: Gyldendal.

Rienecker, L., Harboe, T. \& Jørgensen, P. S. (2005). Vejledning - en brugsbog for opgave og specialevejledere på videregående uddannelser. Frederiksberg: Forlaget Samfundslitteratur.

Schein, E. (1973). Professional education. New York: McGraw Hill.

Schön, D. (1987). Educating the reflective practitioner. Toward a new design for teaching and learning in the professions. San Francisco: Jossey-Bass Publishers.

Strong, T., Sutherland, O., Couture, S., Godard, G. \& Hope, T. (2008). Karl Tomm's collaborative approaches to counselling. Canadian Journal of Counselling and Psychotherapy/Revue canadienne de counseling et de psychothérapie, 42(3).

Strøier, V. (2011). Konsulentens grønspxttebog: Systemisk og eksistentiel tilgang til konsulentarbejde. København: Dansk psykologisk Forlag.

Søholm, T. M., Storch, J., Juhl, A., Dahl, K. \& Molly, A. (2006). Ledelsesbaseret coaching. København. Børsens Forlag.

Tofteskov, J. (1996). Projektvejledning - og organisering af projektarbejde. Frederiksberg: Forlaget Samfundslitteratur.

Tomm, K. (1988). Interventive interviewing: Part III. Intending to ask lineal, circular, strategic, or reflexive questions? Family Process, 27(1), 1-15.

Vestergaard, E. (2006). Den danske forskeruddannelse: Rapporter, evalueringer og anbefalinger 1992 - 2006. Århus: Aarhus Universitet, Dansk Center for Forskningsanalyse.

Wichmann-Hansen, G., Eika, B. \& Mørcke, A. M. (2007). Hvad findes der af litteratur om vejledning? - Litteratursøgning med fokus på publicerede, evidensbaserede studier. Dansk Universitetspædagogisk Tidsskrift, 2007(3), 11-19. 